\title{
Onconase, an anti-tumor ribonuclease suppresses intracellular oxidative stress
}

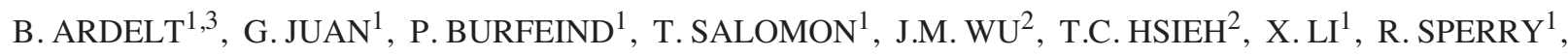 \\ P. POZAROWSKI ${ }^{1}$, K. SHOGEN ${ }^{3}$, W. ARDELT ${ }^{3}$ and Z. DARZYNKIEWICZ ${ }^{1}$ \\ ${ }^{1}$ Brander Cancer Research Institute, New York Medical College, Valhalla, NY 10595; ${ }^{2}$ Department of Biochemistry and \\ Molecular Biology, New York Medical College, Valhalla, NY 10595; ${ }^{3}$ Alfacell Corporation, Bloomfield, NJ 07003, USA
}

Received April 16, 2007; Accepted June 4, 2007

\begin{abstract}
Onconase (ONC), an antitumor ribonuclease from oocytes of a frog Rana pipiens, capable of inducing apoptosis in many cell lines is synergistic with several other anticancer drugs. Since cytotoxic effects of numerous drugs are modulated by reactive oxygen intermediates (ROI), we have studied effects of ONC on the intracellular level of oxidants in several normal cell types as well as tumor cell lines. It is demonstrated for the first time that ONC substantially decreases the content of ROI in all cell lines studied. This effect depends on the ribonucleolytic activity of the enzyme and is due to both, decreased rate of ROI generation and accelerated rate of their degradation. Onconase decreases the mitochondrial transmembrane potential and consequently, generation of ATP. Simultaneously the enzyme decreases the expression of an antiapoptotic protein $\mathrm{Bcl}-2$, and upregulates the proapoptotic Bax protein. These finding are consistent with the enzyme propensity to induce apoptosis. The observed antioxidant activity of ONC may be an important element of its cytotoxicity towards cancer cells. The enzyme seems to exert its biological activities by interfering with the redox system of cellular regulation.
\end{abstract}

\section{Introduction}

Onconase (ONC, Onconase ${ }^{\circledR}$ is a trademark of Alfacell Corporation; Ranpirnase is a generic name of this product), previously known as $\mathrm{P}-30$ protein, is a small $(12 \mathrm{kDa})$ ribo-

Correspondence to: Dr Barbara Ardelt, Alfacell Corp. 225 Belleville Ave., Bloomfield, NJ 07003, USA

E-mail: bardelt@alfacell.com

Abbreviations: ONC, Onconase; TNF- $\alpha$, tumor necrosis factor- $\alpha$; ROI, reactive oxygen intermediates; NF-кB, nuclear factor kappa B; DHRh123, dihydrorhodamine 123; PMA, phorbol myristate acetate; SOD, superoxide dismutase

Key words: Onconase, oxidative stress, ribonuclease, cytotoxicity, apoptosis nuclease isolated from Rana pipiens oocytes (1). Its amino acid sequence (1), crystallographic structure (2) and general mechanism of enzymatic activity (1-4; Ardelt et al, Proc 4th International Meeting on Ribonucleases: Chemistry, Biology, Biotechnology, Groningen, 1996) are similar to those of bovine pancreatic ribonuclease $\mathrm{A}$ and related enzymes. However, unlike most ribonucleases, ONC exhibits in vitro antiproliferative and cytotoxic activity against tumor cell lines (1,3-7) and inhibits growth of certain tumors in mice $(8,9)$. It is presently in phase III clinical trials tested as a potential anticancer modality in patients with malignant mesothelioma $(10,11)$. ONC potentiates effects of a variety of antitumor drugs $(7,12-15)$. The enzyme penetrates the cell, probably via a receptor mediated endocytosis (16) and inhibits protein synthesis by degradation of various species of RNA (6), predominantly tRNA $(17,18)$. The cytostatic and the cytotoxic effects become visible after $48-72 \mathrm{~h}$ of the cell exposure to $\mathrm{ONC}$ and manifest as an arrest of cells in the $\mathrm{G}_{1}$ phase of the cell cycle followed by cell apoptosis (7,19-21). The alkylated form of $\mathrm{ONC}$, retaining only traces of the original enzymatic activity, was not cytotoxic $(1,6)$ and by two orders of magnitude less active in suppression of protein synthesis (6). Considering that observed patient toxicity of ONC in clinical trials is rather low $(10,11)$ it is unclear as to why tumor cells are selectively more sensitive to this drug compared to normal cells.

It was recently postulated that ONC may exert its biological activities by targeting the RNA interference system of regulation of gene expression (22). Structure and function of ONC as well as its therapeutic potential are subjects of a review article (7).

Cellular reduction/oxidation (redox) status affects various aspects of cell function. Oxidative stress can elicit cellular proliferation or activation as well as growth inhibition and apoptosis $(23,24)$. Thus, the cellular redox systems appear to play an important role in cell regulation.

Therefore, in the present study, we have investigated whether ONC can modulate ROI within living cells. The level of oxidants was measured by the methods adapted to flow cytometry in large cell populations of several cell types, exposed for various period of time to pharmacological concentrations of ONC. It was observed that the intracellular level of these markers of oxidative stress was diminished in the presence of ONC. A detailed mechanism by which ONC 
affects ROI levels within the cells is unexplained at present; some hypotheses are discussed later.

\section{Materials and methods}

Cell lines. Fibroblast cell lines: CRL no. 1502 (fetal midscapsular skin), CRL no. 1881 (normal, 78-year-old female breast skin), CRL no. 2077 (normal, 46-year-old female breast skin), and WI-38 lung diploid human fibroblasts, as well as fibrosarcoma and T47D (breast, duct carcinoma, human) were purchased from American Type Culture Collection (Rockville, $\mathrm{MD})$. Jurkat-SN and Jurkat-B $\alpha \mathrm{M}$ were kindly provided by $\mathrm{Dr}$ Douglas Green of the Scripps Institute at La Jolla, CA. Human normal lymphocytes were obtained from the blood of healthy volunteers by density gradient centrifugation as described (2527), washed twice with phosphate-buffered saline (PBS) and re-suspended in RPMI-1640 medium. Cells were cultured at $37^{\circ} \mathrm{C}$ and $5 \% \mathrm{CO}_{2}$, in RPMI-1640 supplemented with $10 \%$ fetal bovine serum, penicillin $(100 \mathrm{U} / \mathrm{ml})$, streptomycin $(100 \mathrm{mg} / \mathrm{ml})$, and $2 \mathrm{mM}$ L-Glutamine. All media, supplements, and antibiotics were obtained from Life Technologies (Grand Island, NY). The cultures were periodically tested for Mycoplasma infection. In order to maintain asynchronous exponential growth, cultures were passaged by diluting to a concentration of $1 \times 10^{5}$ cells $/ \mathrm{ml}$ density and repassaged before approaching $5 \times 10^{5}$ cells/ml density.

Drugs. ONC, and alkylated-ONC were products of Alfacell Corp. (Bloomfield, NJ). Stock solutions (1 mg/ml) were prepared in HBSS; final concentrations are given in figure legends.

Flow cytometry. All analyses were performed with an EPICS Elite ESP flow cytometer/cell sorter (Beckman/Coulter, Miami, FL). Fluorochromes were from Molecular Probes (Eugene, OR, USA) and were excited with an argon laser tuned at $488 \mathrm{~nm}$. Forward-angle light scatter and right-angle light scatter were measured, and fluorescence was detected through a 488-nm blocking filter, a 550-nm band-pass or a 575-nm long-pass. Samples were acquired for 10,000 individual cells. Cell viability was determined by the fluorescence dye propidium iodide (final concentration, $5 \mu \mathrm{g} / \mathrm{ml}$ ) at $630-\mathrm{nm}$ fluorescence emission and by light-scatter properties. Dead cells were gated out of the studies allowing us to correlate the functional changes only to viable cells.

Determination of oxidant content. Oxidants were determined in cells using a probe: dihydrorhodamine 123 (DHRh123). The probe undergoes oxidation to its fluorescent form (Rh123) mainly by hydrogen peroxide but also by other oxidants like hydroperoxides and peroxinitrite. Fluoroscence of Rh123 is detected by the flow cytometer (28).

Oxidative burst. This was measured using a reagent kit developed by Coulter Corporation: CellProbe ${ }^{\mathrm{TM}} \mathrm{DCFH}$, PMA-Oxidative Burst (Enzyme Substrate) (kindly provided by Dr Judy Smith of Coulter). In this procedure, a nonfluorescent probe, dichlorofluorescein diacetate (DCFHDA) undergoes oxidation to highly fluorescent 2',7'-dichlorofluorescein (DCF) by $\mathrm{H}_{2} \mathrm{O}_{2}$ generated by NADPH oxidase and superoxide dismutase and by other oxidants. The determinations were carried out according to the manufacturer's instructions.

Catalase assay. Cells were suspended in $50 \mathrm{mM}$ HEPES, $\mathrm{pH} 7.5$, containing $0.3 \%$ Triton X-100 and $0.2 \mathrm{mM} \mathrm{PMSF}$, at a ratio of $0.1 \mathrm{ml}$ buffer per $1 \times 10^{6}$ cells and by four freezethaw cycles, as modified from published procedures $(29,30)$. The homogenate was maintained on ice for $60 \mathrm{~min}$ with intermittent vortexing, then clarified by microcentrifugation. The supernatant was used as a source of catalase. Catalase activity was assayed by measuring the decomposition rate of hydrogen peroxide $(31,32)$. Varying amounts of cell extracts were added to $1 \mathrm{ml}$ of $17.6 \mathrm{mM} \mathrm{H}_{2} \mathrm{O}_{2}$ in $50 \mathrm{mM}$ phosphate buffer, $\mathrm{pH}$ 7.0. The decrease in absorbance at $240 \mathrm{~nm}$ was followed as a function of time and the first order rate was calculated. One unit of catalase was defined as that causing a decrease of $0.1 \mathrm{U}$ of absorbance per min.

Western blot analysis of the expression of catalase and superoxide dismutase. Cell lysates: cell pellets were resuspended in $10 \mathrm{mM}$ HEPES containing $90 \mathrm{mM} \mathrm{KCl}, 1.5 \mathrm{mM} \mathrm{Mg}(\mathrm{OAc})_{2}$, $1 \mathrm{mM}$ DTT, $0.5 \%$ NP40 and 5\% glycerol (pH 7.5) supplemented with $0.5 \mathrm{mM}$ phenylmethylsulfonylfluoride (PMSF), $10 \mu \mathrm{g} / \mathrm{ml}$ each of aprotinin, pepstatin, leupeptin, and lysed by 3 freeze/thaw cycles. Cell-free extracts were obtained by microcentrifugation.

Western blot analysis: cytostolic proteins were resolved by SDS-PAGE, and electrophoretically transferred to a nitrocellulose membrane. Non-specific binding was blocked with $3 \%$ milk in TBST (20 mM Tris- $\mathrm{HCl}, 0.05 \%$ Tween-20). Antibodies to superoxide dismutase (both $\mathrm{Cu} / \mathrm{Zn}$ and $\mathrm{Mn}$ ) were diluted 1:750, while that to catalase was diluted 1:1000. Following incubation with respective primary and secondary antibodies, membranes were probed with alkaline phosphatase-conjugated IgG (Santa Cruz, 1:1500) or horseradish peroxidase-conjugated IgG (Santa Cruz, 1:2000). Specific immunoreactive bands were identified by color reaction or enhanced chemiluminescence, respectively. Re-probing was carried out following incubation of membranes with stripping buffer (62.5 mM Tris-HCl, pH 6.7, 100 mM 2-mercaptoethanol, $2 \% \mathrm{SDS}$ ) at $50^{\circ} \mathrm{C}$ for $20 \mathrm{~min}$.

Western blot analysis of the expression of Bcl-2 and Bax. The cells were washed twice with cold PBS, then lysed in $100 \mathrm{mM}$ TRIS, pH 8.0, containing 1\% sodium deoxycholate, $300 \mathrm{mM}$ vandate, $0.15 \mathrm{M} \mathrm{NaCl}, 0.1 \%$ dodecyl sulphate, $0.1 \mathrm{mg} / \mathrm{ml}$ PMSF, $1 \mu \mathrm{g} / \mathrm{ml}$ aprotinin, and 1\% NP-40. After $30 \mathrm{~min}$ on ice, the lysates were centrifuged at $14000 \mathrm{~g}$ at $4^{\circ} \mathrm{C}$ for $20 \mathrm{~min}$. The supernatants were collected and the samples were applied on $10 \%$ SDS polyacrylamide gels. Electrophoresis was performed at $130 \mathrm{~V}$ at $4^{\circ} \mathrm{C}$ in room temperature for $1 \mathrm{~h}$, then the proteins were transferred to nitrocellulose membrane at $100 \mathrm{~V}$ at $4^{\circ} \mathrm{C}$ for $1 \mathrm{~h}$, followed by blocking with $5 \%$ non-fat dry milk in 1X TBS for $1 \mathrm{~h}$, and incubated with Bcl-2 and Bax monoclonal antibodies (Becton-Dickinson/Pharmingen, San Jose, CA) at dilution 1:200 at room temp for $1 \mathrm{~h}$. The blots were washed 3 times with $1 \%$ milk in $1 \mathrm{X}$ TBS, and incubated $1 \mathrm{~h}$ at ambient temperature with diluted (1:2000) horseradish peroxidase-conjugated to goat anti-mouse $\mathrm{IgG}$ 


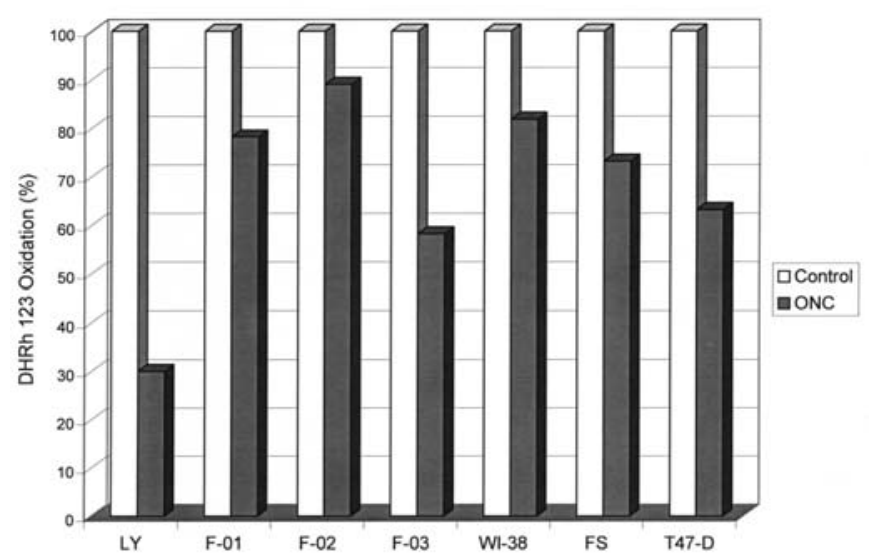

Figure 1. Effect of Onconase on the content of oxidants in cultured cells. The cells $\left(1 \times 10^{5} / \mathrm{ml}\right)$ were incubated in RPMI-1640 medium with or without Onconase, 5 or $10 \mu \mathrm{g} / \mathrm{ml}\left(4.23 \times 10^{-7} \mathrm{M}\right.$ or $\left.8.46 \times 10^{-7} \mathrm{M}\right)$ for $48 \mathrm{~h}$. Cell suspensions were centrifuged at $300 \mathrm{x}$ g for $5 \mathrm{~min}$, the pellets re-suspended in the medium containing the DHRh123 probe, incubated for an additional $30 \mathrm{~min}$ at $37^{\circ} \mathrm{C}$ and subjected to flow cytometry as described in Materials and methods. The following cell lines and Onconase concentrations were used: Ly, lymphocytes (ONC $10 \mu \mathrm{g} / \mathrm{ml}$ ); F-01, skin fibroblasts from human fetal skin $(10 \mu \mathrm{g} / \mathrm{ml}) ; \mathrm{F}-02$, skin fibroblast from a 78-year-old donor (10 $\mu \mathrm{g} / \mathrm{ml}) ; \mathrm{F}-03$, skin fibroblasts, 46-year-old donor (5 $\mu \mathrm{g} / \mathrm{ml})$; Wi-38, human lung tissue, 3-month gestation, diploid $(10 \mu \mathrm{g} / \mathrm{ml})$; Fs, human fibrosarcoma $(5 \mu \mathrm{g} / \mathrm{ml})$; and $\mathrm{T} 47-\mathrm{D}$, human breast ductal carcinoma $(5 \mu \mathrm{g} / \mathrm{ml})$.

(Amersham, Arlington Heights, IL). Blots were washed 3 times and developed by using enhanced chemiluminescence according to the manufacturer's instructions.

Determination of ATP. The ATP bioluminescent assay kit (Sigma Chemical Co., St. Louis, MO) was used for this purpose. HL-cells were incubated with $10 \mu \mathrm{g} / \mathrm{ml}$ of ONC for $72 \mathrm{~h}$ harvested by centrifugation and lysed with $0.2 \mathrm{ml}$ of ice-cold $3.0 \mathrm{M}$ perchloric acid for $15 \mathrm{~min}$. Then $40 \mu \mathrm{l}$ of $0.5 \mathrm{M}$ EDTA, $\mathrm{pH} 8.0$ was added to the cell lysate and the mixture was centrifuged at $5000 \mathrm{~g}$ for $10 \mathrm{~min}$. The supernatant was neutralized to $\mathrm{pH}$ 7.6-7.8 with a neutralizing buffer consisting of $2.0 \mathrm{M} \mathrm{KOH}, 0.4 \mathrm{M}$ imidiazole and $0.4 \mathrm{M} \mathrm{KCl}$ and clarified by centrifugation. The supernnatants were read on a Wallac Victor 21420 Multilabel Counter using the luminometry recorder (measuring light emission, no filter). ATP standard curve was used for calculations.

\section{Results}

Onconase reduces the level of oxidants in cultured cells. Figs. 1-3 show the effect of ONC on the ability of different cell types to oxidize the DHRh123 probe. It is commonly accepted that the formation of the oxidized fluorescent product (Rh123) is mediated by hydrogen peroxide and some other oxidants (see Materials and methods). The intensity of fluorescence signal correlates with the content of these oxidants in cells.

We demonstrate that ONC significantly inhibited cell induced oxidation of DHRh 123 in all studied cell lines (Fig. 1), this effect was also observed in both Jurkat cell lines (Fig. 2), one expressed non-functional NF- $\mathrm{KB}(\mathrm{B} \alpha \mathrm{M})$ and the parent cell

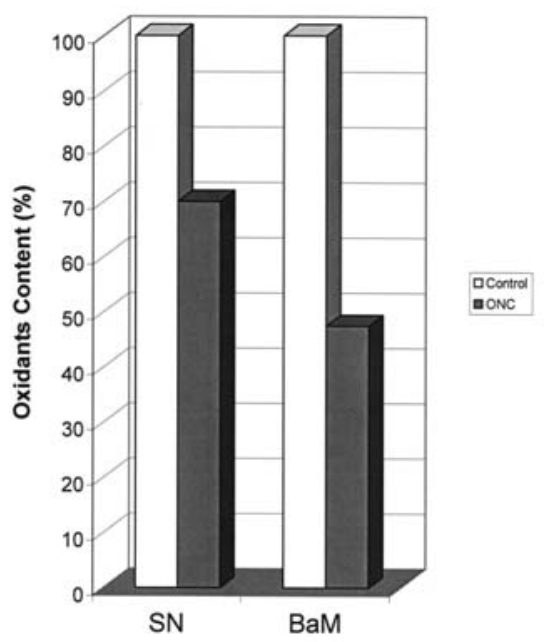

Figure 2. Effect of Onconase on the content of oxidants in Jurkat cell lines. Experimental conditions were as described in Fig. 1 except that incubation time with Onconase $(10 \mu \mathrm{g} / \mathrm{ml})$ was $72 \mathrm{~h}$. Two lines of Jurkat cells were used: $\mathrm{SN}$, the parent line capable of activation of $\mathrm{NF \kappa B}$, and $\mathrm{B} \alpha \mathrm{M}$ with an impaired activation system of this transcription factor. The figure presents mean values of 6 experiments. The mean values and standard deviations of oxidants suppression (percentages, six experiments) in Onconase treated cells were $22.1 \pm 7.5$, and $44.8 \pm 7.8$, for $\mathrm{SN}$ and $\mathrm{B} \alpha \mathrm{M}$ lines, respectively.

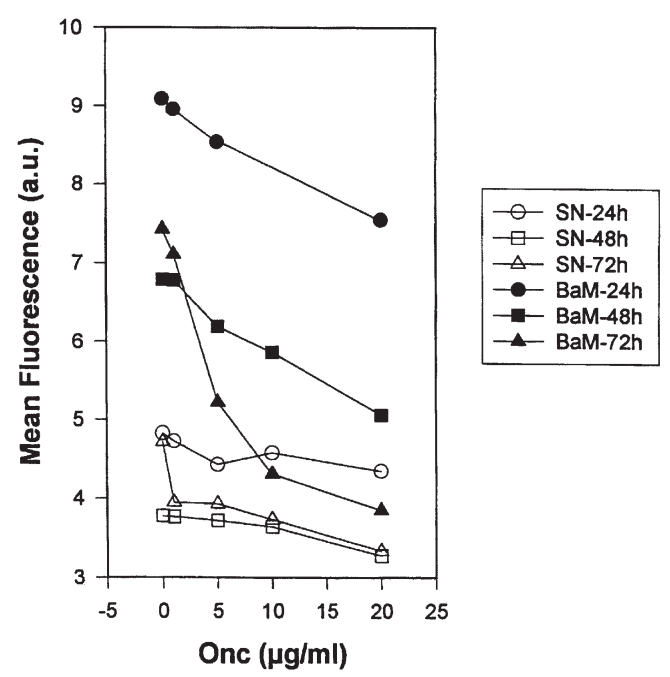

Figure 3. Effect of increasing onconase concentration and incubation time on the content of oxidants in Jurkat cell lines. Experimental conditions as in Fig. 1 except that enzyme concentrations and incubation times of the cells with Onconase were as indicated in the figure.

line $(\mathrm{SN})$ with preserved ability to activate this transcription factor. Interestingly, the former cell line had nearly 2 -fold higher level of oxidants in control group then SN control group. $\mathrm{B} \alpha \mathrm{M}$ cells were also more sensitive to the ROI suppressive action of ONC. Suppression of ROI by ONC in studied cells is time as well as concentration dependent (Fig. 3).

Suppression of oxidants depends on onconase enzymatic activity. To test whether the observed effect is related to ONC ribonuclease activity, an inactivated preparation of this enzyme was also studied (Fig. 4). Alkylated ONC retaining $<0.5 \%$ of the original enzymatic activity did not affect the 


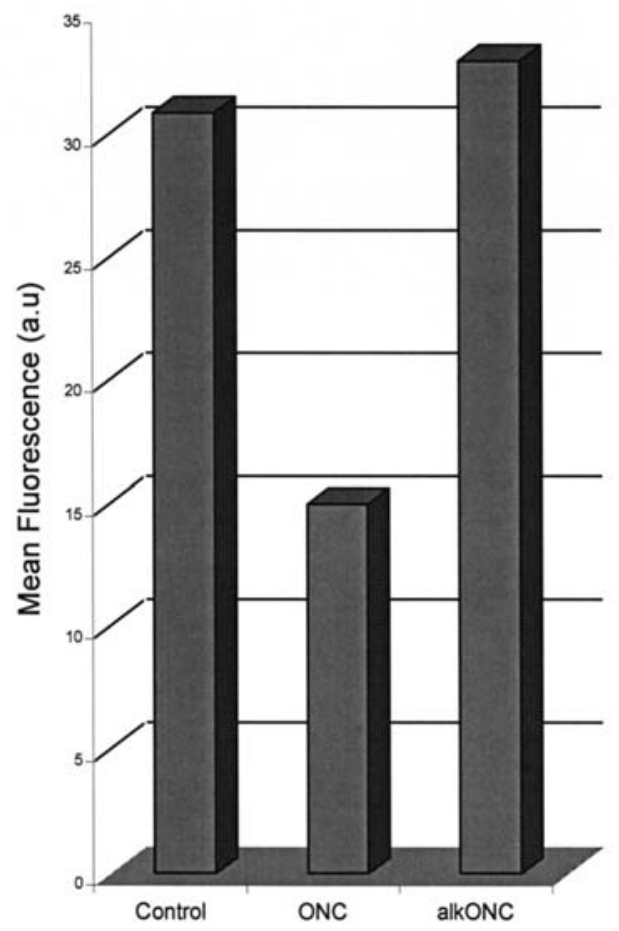

Figure 4. Effect of Onconase and its enzymatically inactive form on the content of oxidants in Jurkat $\mathrm{B} \alpha \mathrm{M}$ cells. The cells were incubated with either native Onconase or its alkylated form retaining $<0.5 \%$ of the original enzyme activity. Enzyme concentration was $10 \mu \mathrm{g} / \mathrm{ml}$ and the incubation time was $72 \mathrm{~h}$. Other experimental conditions were as in the legend for Fig. 1.

ability of cells to oxidize the DHRh 123 probe. Thus, enzymatic activity of ONC appears to be critical for the observed decrease of ROI in exposed cells.

Decrease of oxidants in Onconase treated cells is due to both diminished biosynthesis and increased degradation. The observed suppression of ROI could result from their reduced biosynthesis and/or from enhanced degradation. Therefore, we also studied the rate of ROI generation and the catalase activity in ONC treated cells. Genaration of ROI is catalyzed by two 'oxidative burst' enzymes. NADPH oxidase generates superoxide anion $\left(\mathrm{O}_{2}^{-}\right)$that is next converted to hydrogen peroxide by superoxide dismutase (SOD). Hydrogen peroxide is, in turn, degraded to oxygen and water by catalase. Generation of ROI in studied cells was induced by phorbol myristate in the presence and absence of ONC. Phorbol myristate induced oxidative burst in Jurkat $\mathrm{B} \alpha \mathrm{M}$ but not in Jurkat SN cells. Treatment with ONC substantially reduced the rate of ROI generation in Jurkat $\mathrm{B} \alpha \mathrm{M}$ cells (Fig. 5) but did not affect this process in Jurkat SN cells (Fig. 6). As shown in Table I, catalase activity in both Jurkat cell lines was significantly increased after incubation $72 \mathrm{~h}$ with ONC. The effect was more pronounced in $\mathrm{B} \alpha \mathrm{M}(60 \%)$ compared to SN $(42 \%)$ cells. It is noteworthy that in untreated Jurkat SN cells catalase activity was lower by about $49 \%$ than in untreated Jurkat B $\alpha \mathrm{M}$ cells.

Expression of superoxide dismutase and catalase in Jurkat cell lines. A question arose whether the observed decrease in ROI generation rate was due to the affected expression of the appropriate enzymes. It turned out that ONC decreased the

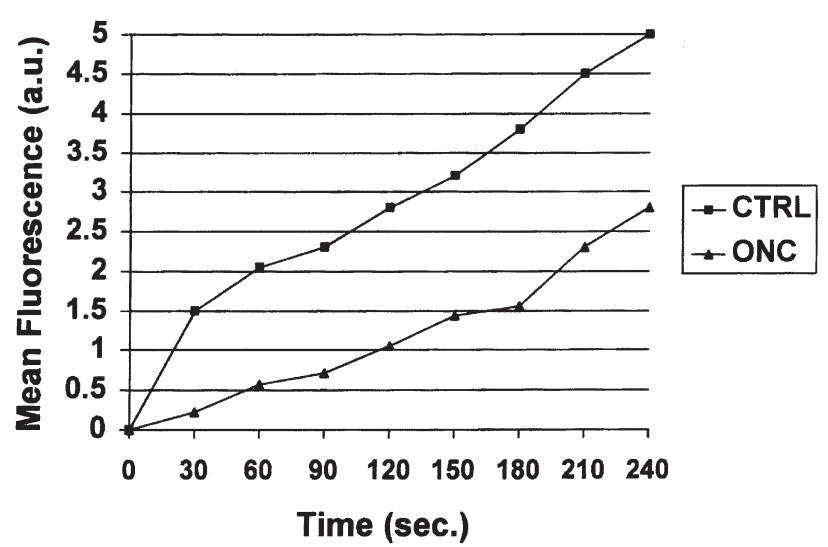

Figure 5. Effect of Onconase on the oxidative burst generated in Jurkat $\mathrm{B} \alpha \mathrm{M}$ cells by phorbol myristate. The cells $\left(1 \times 10^{5} / \mathrm{ml}\right)$ were incubated in RPMI-1640 medium with Onconase, $10 \mu \mathrm{g} / \mathrm{ml}\left(8.46 \times 10^{-7} \mathrm{M}\right)$ for $24 \mathrm{~h}$, then the enzyme concentration was adjusted to $20 \mu \mathrm{g} / \mathrm{ml}$, the cells were incubated for additional $10 \mathrm{~min}$, centrifuged and washed 3 times with HBSS. Oxidative burst was determined as described in Materials and methods.

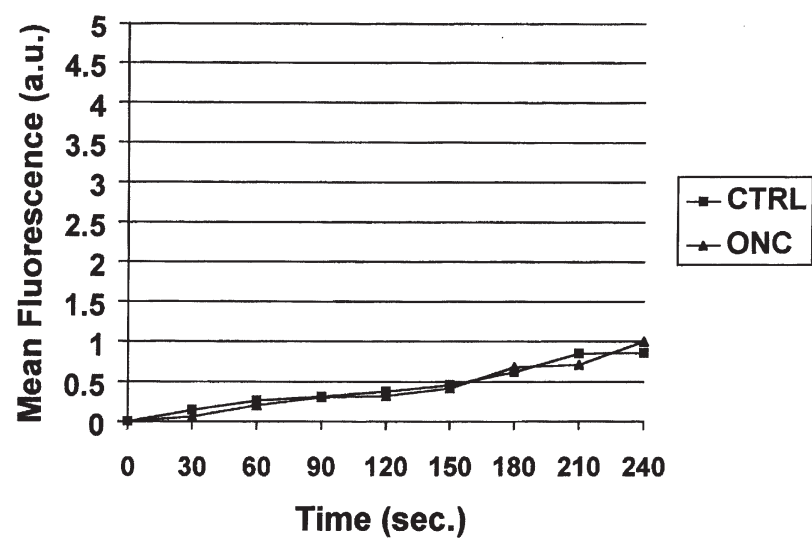

Figure 6. Effect of Onconase on the oxidative burst generated in Jurkat SN cells by phorbol myristate. Experimental conditions and oxidative burst determination as in Fig. 5.

Table I. Catalase activity in Jurkat cells treated with Onconase.

Catalase activity

(U/mg of protein)

Cell line Control Onconase treated Stimulation (\%)

\begin{tabular}{llll}
\hline Jurkat SN & $11.8 \pm 5(9)$ & $16.7 \pm 4(9)$ & 41.8 \\
Jurkat B $\alpha \mathrm{M}$ & $17.6 \pm 3(9)$ & $28.2 \pm 9(6)$ & 60.4 \\
\hline
\end{tabular}

The cells were incubated with Onconase $(10 \mu \mathrm{g} / \mathrm{ml})$ for $72 \mathrm{~h}$. Catalase activity was determined as described in the experimental section. The numbers represent mean values \pm standard deviation; number of experiments is given in parentheses.

expression of SOD by about $30 \%$ in $\mathrm{B} \alpha \mathrm{M}$ cells while the ONC did not affect SOD expression in SN Jurkat cells. Catalase expression in both Jurkat cell lines was not effected by ONC (Fig. 7). 

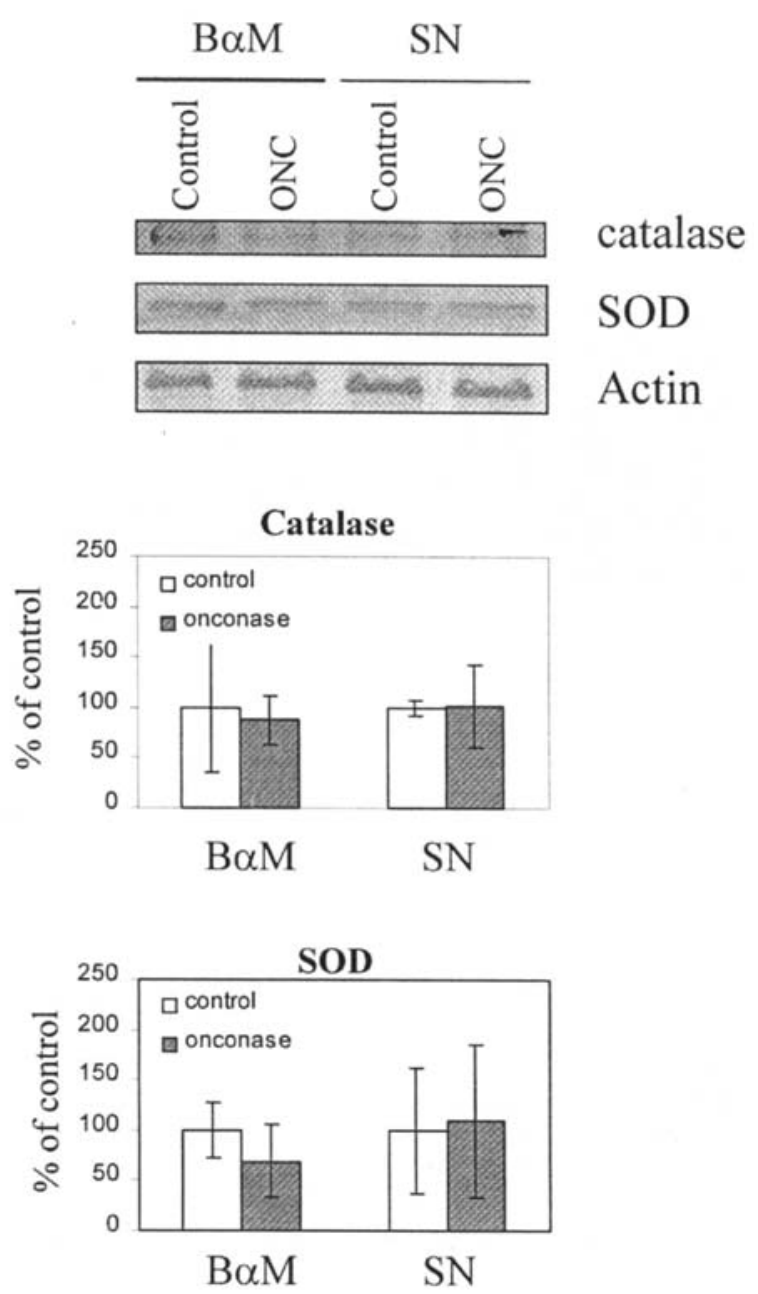

Figure 7. Onconase increases the expression of superoxidase dismutase in Jurkat $\mathrm{B} \alpha \mathrm{M}$ and $\mathrm{SN}$ cell lines. Western blot analysis was performed as described in Materials and Methods. SOD, superoxide dismutase.

Mitochodria and Onconase. ONC is known to induce apoptosis in many tumor cells. Therefore, we also studied some mitochondrial determinants of apoptosis in cells treated with this enzyme. The expression of Bax, a pro-apoptotic protein increased while that of $\mathrm{Bcl}-2$, the mitochondrial anti-apoptotic
Table II. Effect of Onconase on the content of ATP in U937 cells.

ATP content (pmoles $/ 10^{6}$ cells)

\begin{tabular}{lll}
\hline Control & 1.45 & $0.17(2)$ \\
ONC & 0.77 & $0.04(2)$ \\
\hline
\end{tabular}

The cells were incubated with or without ONC $(10 \mu \mathrm{g} / \mathrm{ml})$ for $72 \mathrm{~h}$ and ATP level was determined as described in Materials and methods.

protein was decreased (Fig. 8). Mitochondral transmembrane potential (data not shown) and the ATP level (Table II) were decreased in ONC-treated HL-60 cells.

\section{Discussion}

We demonstrated that treatment of cells in cultures with ONC reduces intracellular oxidative stress by suppressing ROI generation and promoting their degradation. This observation seems important for understanding ONC anti-tumor activity since it was reported by other authors (33) that oxidative stress can interfere with cancer chemotherapy. Apoptosis of Burkitt lymphoma cells induced by several chemotherapy drugs including doxorubicin, was inhibited by hydrogen peroxide (33). Therefore, the anti-oxidative function of ONC may be an important element of its antiproliferative/ cytotoxic activity towards cancer cells and a possible mechanism of its well-documented synergism with other anti-cancer agents (12-15).

ONC is presently undergoing clinical trials for treatment of malignant mesothelioma and our findings are particularly relevant in the view of growing data on the pathogenesis of asbestos-induced diseases. Asbestos fibers cause oxidative stress, i.e., generate ROI in mesothelial cells (24,34-36). Our data indicate that $\mathrm{ONC}$ has a propensity to reverse this effect. Phagocytosis of asbestos by macrophages leads to a release of TNF- $\alpha$ and, consequently, to activation of NF-кB (36), a redox associated transcription factor $(37,38)$. Again, this
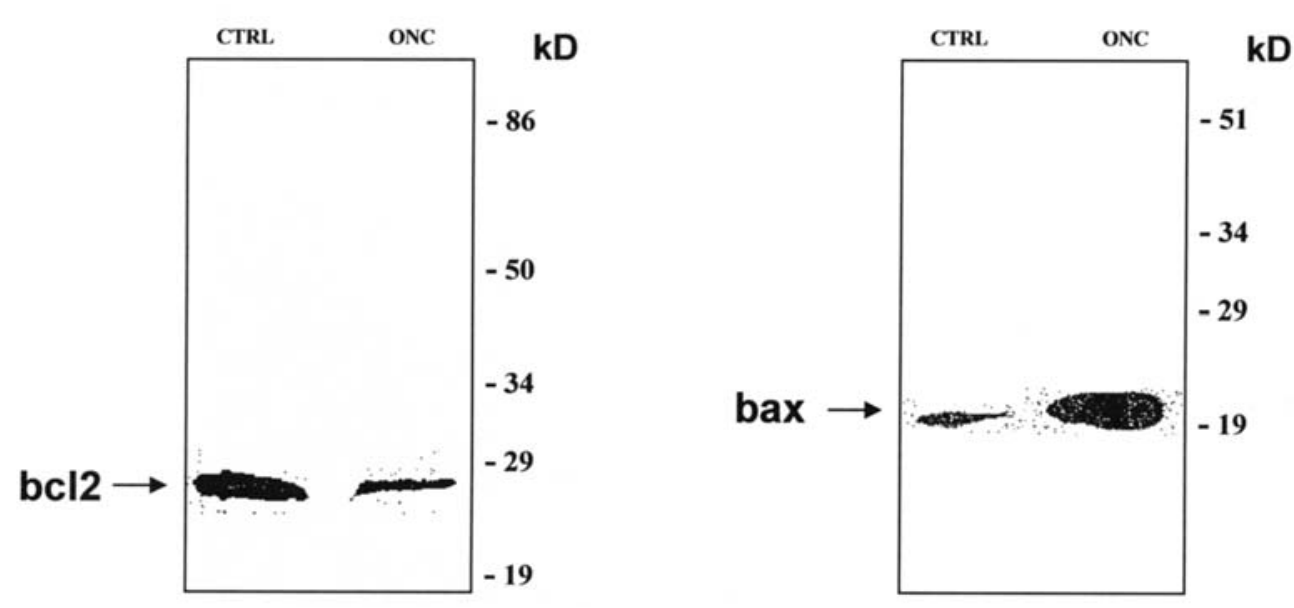

Figure 8. Treatment of HL-60 cells with Onconase decreases the expression of bcl 2 and upregulates bax protein. The cells were incubated with ONC (10 $\mu$ g/ml) for $72 \mathrm{~h}$ and the expression of both proteins was tested as described in Materials and methods. 
effect can be reversed by $\mathrm{ONC}$ as we previously reported that this enzyme reduced $\mathrm{NF}-\mathrm{\kappa B}$ expression and its translocation to nuclei in cultured Jurkat acute T-lymphocytic leukemia cells (39). NF- $\mathrm{NB}$ is involved in the activation of survival pathways and it was proposed that its activation by asbestos leads to a survival of mesothelial cells with asbestos-induced DNA damage and oncogenesis follows (35).

Oxidative stress is known to induce thioredoxin which, in turn, reduces a disulphide bond involving cysteine residue 62 of NF- $\kappa \mathrm{B}$ enabling the transcription factor to bind DNA $(24,40)$. Thus, a decrease of NF- $\mathrm{KB}$ activation by ONC may be due to the suppression of oxidative stress by this enzyme as reported herein. The mechanism of the latter is not well understood. Cell treatment with ONC leads to downregulation of SOD, one of the enzymes generating ROI and simultaneously increases catalase activity (Table I), the enzyme degrading hydrogen peroxide. Those effects depend on ONC ribonuleolytic activity since they did not occur when the enzyme inactivated by alkylation of its active site histidines, was used.

As we found before, ONC may lower the expression of certain genes and simultaneously up-regulate other genes (41). We hypothesized that this might be due to enzyme targeting, the micro-RNA and/or short interfering RNA regulatory pathways (22). This may be considered as a possible mechanism for the observed reduction of SOD expression. However, expression of catalase was unaffected and the nature of its activation by ONC remains unknown.

The present report provides another example of the differential effect of ONC upon gene expression. The expression of $\mathrm{Bcl}-2$, an anti-apoptotic mitochondrial protein was decreased and that of pro-apoptotic Bax, increased in ONC treated HL-60 cells. This is in accordance with the enzyme ability to elicit apoptosis and again, may be due to the postulated ONC effect on the RNA interference system.

Our previous and present results demonstrate that ONC elicits apoptosis by typical mechanisms via activation of caspases (21), destabilization of mitochondrial transmembrane potential (unpublished data), decreasing ATP level, and differential effects on Bcl-2 and Bax expression. However, Iordanov et al (20) reported ONC-induced apoptosis in HeLa cells with marginal release of cytochrome $\mathrm{c}$ and no effect on the expression of Bax and Bcl-2. Most recently, ONC-induced, caspase independent death of neuroblastoma cells was reported (42). These apparent discrepancies between the data reported by different laboratories could be related to different cell lines used for the studies. In neuroblastoma, over-expression of Bcl-2 and, therefore, stabilization of mitochondrial membrane could have prevented the intrinsic apoptosis pathway (42).

Detailed mechanisms of ONC biological activities are not fully understood. The data discussed here seem to indicate that ONC may interfere with at least two major regulatory systems, redox regulation of cellular activation and RNA interference. This enzyme may have a therapeutic potential not only in cancer but also in conditions pathogenetically related to oxidative stress and/or activation of $\mathrm{NF}-\kappa \mathrm{B}$, like inflammation, autoimmune diseases, atherosclerosis, and septic shock.

\section{Acknowledgements}

This work was supported in part by National Cancer Institute Grant CA R01 2874. The authors wish to thank D. Douglas Green of the Scripps Institute at La Jolla, CA for the generous gift of Jurkat-SN and Jurkat-B $\alpha \mathrm{M}$ cells and Dr Judy Smith of Coulter Corporation for the oxidative burst reagent kit.

\section{References}

1. Ardelt W, Mikulski SM and Shogen K: Amino acid sequence of an anti-tumor protein from Rana pipiens oocytes and early embryos. J Biol Chem 245: 245-251, 1991.

2. Mosimann SC, Ardelt W and James MNG: Refined $1.7 \AA$ X-ray crystallographic structure of P-30 protein, an amphibian ribonuclease with anti-tumor activity. J Mol Biol 236: 1141-1153, 1994.

3. Ardelt W, Lee H, Randolph G, Viera A, Mikulski SM and Shogen K: Enzymatic characterization of Onconase ${ }^{\circledR}$, a novel ribonuclease with anti-tumor activity. Prot Sci 3 (Suppl. 1): 137-147, 1994.

4. Boix E, Wu Y-N, Vasandani M, Saxena SK, Ardelt W, Ladner J and Youle RJ: Role of the N terminus in RNase A homologues: differences in catalytic activity, ribonuclease inhibitor interaction and cytotoxity. J Mol Biol 257: 992-1007, 1996.

5. Darzynkiewicz Z, Carter S, Mikulski SM, Ardelt W and Shogen K: Cytostatic and cytotoxic effects of Pannon (P-30 protein), a novel anticancer agent. Cell Tissue Kinet 21: 169-1882, 1988.

6. Wu Y-N, Mikulski SM, Ardelt W, Rybak S and Youle RJ: Cytotoxic ribonuclease. Study of the mechanism of onconase cytotoxicity. J Biol Chem 268: 1686-1693, 1993.

7. Saxena SK, Shogen K and Ardelt W: Onconase ${ }^{\circledR}$ and its therapeutic potential. Lab Med 34: 380-387, 2003.

8. Mikulski SM, Ardelt W, Shogen K, Bernstein E and Menduke H: Striking increase of survival of mice bearing M109 Madison carcinoma treated with a novel protein from amphibian embryos. J Natl Cancer Inst 82: 151-153, 1990.

9. Lee I, Lee YH, Mikulski SM, Lee J, Covone K and Shogen K: Tumoricidal effects of Onconase on various tumors. J Surg Oncol 73:174-171, 2000.

10. Constanzi J, Sidransky D, Navon A and Goldsweig H: Ribonucleases as a novel pro-apoptotic anticancer strategy: review of the preclinical and clinical data for ranpirnase. Cancer Invest 23: 643-650, 2005.

11. Pavlakis N and Vogelzang N: Ranpirnase - an antitumour ribonuclease: its potential role in malignant mesothelioma. Expert Opin Biol Ther 6: 391-399, 2006.

12. Mikulski SM, Viera A, Ardelt W, Menduke H and Shogen K: Tamoxifen and trifluoroperazine (Stelazine) potentiate cytostatic/cytotoxic effects of $\mathrm{P}-30$ protein a novel protein possessing anti-tumor activity. Cell Tissue Kinet 23: 237-246, 1990.

13. Mikulski SM, Viera A and Shogen $\mathrm{K}$ : In vitro synergism between a novel amphibian oocytic ribonuclease (Onconase ${ }^{\circledR}$ ) and tamoxifen, lovastatin and cisplatin, in human OVCAR-3 ovarian carcinoma cell line. Int J Oncol 1: 779-785, 1992.

14. Rybak M, Pearson JW, Fogler WE, Volker K, Spence SE, Newton DL, Mikulski SM, Ardelt W, Riggs CW, Kung H-F and Longo DR: Ehancement of vincristine cytotoxicity in drug-resistant cells by simultaneous treatment with onconase, an antitumor ribonuclease. J Natl Cancer Inst 88: 749-752, 1996.

15. Deptala A, Halicka HD, Ardelt B, Ardelt W, Mikulski SM, Shogen K and Darzynkiewicz Z: Potentiation of tumor necrosis factor induced apoptosis by onconase. Int J Oncol 13: 11-16, 1998.

16. Rodriques M, Torrent G, Bosch M, Rayne F, Dubremetz JF, Ribo M, Benito A, Vilanova $\mathrm{M}$ and Beaumella B: Intracellular pathway of Onconase that enables its delivery to the cytosol. J Cell Sci 120: 1405-1411, 2007.

17. Lin JJ, Newton DL, Mikulski SM, Kung HF, Youle RJ and Rybak SM: Characterization of the mechanism of cellular and free protein synthesis inhibition antitumor ribonuclease. Biochem Biophys Res Commun 204: 156-162, 1994. 
18. Saxena SK, Sirdeshmukh R, Ardelt W, Mikulski, SM, Shogen K and Youle RJ: Entry into cells and selective degradation of tRNAs by a cytotoxic member of the RNse A family. J Biol Chem 277: 15142 -15146, 2002.

19. Halicka HD, Murakami T and Papageorgio CN: Induction of differentiation of leukeamic (HL-60) or prostate cencer (LNCaP JCA-1) cells potentiates apoptosis triggered by onconase. Cell Prolif 33: 407-417, 2000.

20. Iordanov MS, Ryabinina OP, Wong J, Dinh TH, Newton DL, Rybak SM and Magun BE: Molecular determinants of apoptosis induced by the cytotoxic ribonuclease onconase: evidence for cytotoxic mechanisms different from inhibition of protein synthesis. Cancer Res 60: 1983-1984, 2000.

21. Grabarek J, Ardelt B, Du L and Darzynkiewicz Z: Activation of caspases and serine proteases during apoptosis induced by onconase (Rapinase). Exp Cell Res 278: 61-71, 2002.

22. Ardelt B, Ardelt W and Darzynkiewicz Z: Cytotoxic ribonucleases and RNA interference (RNAi). Cell Cycle 2: 10-12, 2003.

23. Nakamura $H$, Nakamura $K$ and Yodoi J: Redox regulation of cellular activation. Annu Rev Immunol 15: 351-369, 1997.

24. Shukla A, Gulumian M, Hey TK, Kamp D, Rachman Q and Mossman BT: Multiple roles of oxidants in the pathogenesis of asbestos-induced diseases. Free Radic Biol Med 1: 1117-1129, 2003.

25. Juan G, Gong J, Traganos F and Darzynkiewicz Z: Unscheduled expression of cyclins D1 and D3 in human tumor cell lines. Cell Prolif 29: 259-266, 1996.

26. Juan G, Pen W and Darzynkiewicz Z: DNA segments sensitive to single strand specific nucleases are present in chromatin of mitotic cells. Exp Cell Res 27: 197-202, 1996.

27. Gong J, Bhatia U, Traganos F and Darzynkiewicz Z: Expression of cyclins A, D2 and D3 in individual normal mitogen stimulated lymphocytes and MOLT-4 leukemic cells analyzed by multiparameter flow cytometry. Leukemia 9: 893-899, 1995.

28. Juan S, Pallardo FV, Pla R, Pellin A, Juan G, O'Connor JE, Estrela GM, Miquel $\mathbf{J}$ and Vina G: Ageing of the liver: ageassociated mitochondrial damage in intact hepatocytes. Hepatology 24: 1199-1205, 1996.

29. Speier $C$ and Newburger PE: Changes in superoxide dismutase, catalase, the glutathione cycle during induced myeloid differentiation. Arch Biochem Biophys 251: 551-557, 1986.

30. Kassugai I and Yamada M: High production of catalase in hydrogen peroxide-resistant human leukemia HL-60 cell lines. Leukemia Res 16: 173-179, 1992.

31. Lin F, Jackson VE and Girotti AW: Amplification and hyperexpression of the catalase gene in selenoperoxidase-deficient leukemia cells. Arch Biochem Biophys 317: 7-18, 1995.
32. Abel H: Catalase. In: Methods of Enzymatic Analysis. Vol. 2. Bergmeyer HU (ed.). Academic Press, New York, pp673-684, 1974.

33. Shacter E, Williams JA, Hinson RM, Senturker and Lee Y-J: Oxidative stress interferes with cancer chemotherapy: inhibition of lymphoma cell apoptosis and phagocytosis. Blood 96: 307-313, 2000.

34. Kinnula VL: Oxidant and antioxidant mechanisms of lung disease caused by asbestos fibers. Eur Respir J 14: 706-716, 1999.

35. Haegens A, van der Vliet A, Butnor KJ, Heintz N. Taatjes D, Hemenway D, Vacek P, Freeman BA, Hazen SL, Brennan ML and Mossman BT: Asbestos-induced lung inflammation and epithelial cell proliferation are altered in myeloperoxidase-null mice. Cancer Res 65: 9670-9677, 2000.

36. Yang H, Boccheta M, Korczynska B, Elmishad AG, Chen Y, Liu Z, Bubici C, Mossman BT, Pass HI, Testa JR, Franzoso G and Carbone M: TNF- $\alpha$ inhibits asbestos-induced cytotoxicity via a NF- $\mathrm{BB}$-dependent pathway, a possible mechanism for asbestos-induced oncogenesis. Proc Natl Acad Sci USA 103: 10397-10402, 2006.

37. Hayashi T, Ueno $\mathrm{Y}$ and Okamoto T: Oxidoreductive regulation of nuclear factor kappa B. Involvement of a cellular reducing catalyst thioredoxin. J Biol Chem 268: 11380-11388, 1993.

38. Flohe L, Brigelius-Flohe R, Saliou C, Traber MG and Packer L: Redox regulation of NF-Kappa B activation. Free Radic Biol Med 22: 1115-1126, 1997.

39. Tsai SY, Ardelt B, Hsiech T-C, Darzynkiewicz Z, Shogen K and Wu JM: Treatment of Jurkat acute T-lymphocytic leukemia cells by onconase (Ranpirnase) is accompanied by an altered nucleoplasmic distribution and reduced expression of transcription factor NF-кB. Int J Oncol 25: 1745-1752, 2004.

40. Matthews JR, Wakasugi N, Virelizier JL, Yodoi J and Hay RT: Thioredoxin regulates the DNA binding activity of NF- $\mathrm{kB}$ by reduction of a disulphide bond involving cysteine 62 . Nucleic Acids Res 20: 3821-3830, 1992.

41. Juan G, Ardelt B, Li X, Mikulski SM, Shogen K, Ardelt W, Mittelman A and Darzynkiewicz Z: $\mathrm{G}_{1}$ arrest of U937 cells by onconase is associated with suppression of cyclin D3 expression, induction of $\mathrm{p} 16^{\mathrm{INK} 4 \mathrm{~A}}, \mathrm{p} 21^{\mathrm{WAF} 1 / \mathrm{CIP} 1}$ and $\mathrm{p} 27^{\mathrm{KIP}}$ and decreased pRb phosphorylation. Leukemia 12: 1241-1248, 1998.

42. Michealis M, Cinatl J, Anad P, Rothweiler F, Kotchetkov R, von Deimling A, Doerr HW, Shogen K and Cinatl J Jr: Onconase induces caspase-independent cell death in chemoresistant neuroblastoma cells. Cancer Lett (In press). 